\title{
Physical activity and sedentary behavior: a review of longitudinal studies of weight and adiposity in youth
}

\author{
A Must ${ }^{1 *}$ and DJ Tybor ${ }^{2}$ \\ ${ }^{1}$ Department of Public Health and Family Medicine, Tufts University School of Medicine, Boston, MA, USA; and ${ }^{2}$ Friedman \\ School of Nutrition, Tufts University, Boston, MA, USA
}

\begin{abstract}
AIM: To review the published prospective observational studies of the relationship of physical activity and sedentary behavior with the development of overweight and adiposity, with an emphasis on methodologic issues.

METHODS: Sample size, population studied, length of follow-up, assessment of exposure (physical activity, inactivity, or sedentary behavior), assessment of outcome (relative weight, overweight, \% body fatness, adiposity), statistical approach, and main findings were extracted, summarized, and key methodological issues highlighted.

RESULTS: In total, 17 studies of physical activity and 15 studies of inactivity/sedentary behavior were identified; as these were not mutually exclusive, 20 unique studies were reviewed. Results were mixed, with most studies showing an inverse association of physical activity with weight or fatness outcomes and/or a direct association of inactivity/sedentary behavior with weight or fatness outcomes. The effects identified were generally of small magnitude. Imprecise measurement of activity exposures likely weakens the observed relationships. Most studies used a pre-post design and had limited duration of follow-up $(\leq 2 y)$. Studies with longer and more frequent follow-up did not always use the most advantageous statistical approach.

CONCLUSIONS: On balance, the available evidence from prospective observational studies suggests that increased physical activity and decreased sedentary behavior are protective against relative weight and fatness gains over childhood and adolescence. In addition to improved measurement methods, longer and more frequent follow-up as well as truly longitudinal analysis methods would help establish these important prevention and intervention targets, and identify subgroups or development periods where interventions would likely be effective.
\end{abstract}

International Journal of Obesity (2005) 29, S84-S96. doi:10.1038/sj.ijo.0803064

Keywords: physical activity; inactivity; sedentary behavior; screen time; overweight

\section{Introduction}

Approximately one-half century ago, Mayer ${ }^{1}$ noted the importance of physical activity in the etiology of obesity. Also, at that distant time, it was speculated that inactivity might play a more important role than diet in the development of obesity. ${ }^{2}$ Low levels of physical activity and large amounts of inactivity or sedentary behavior are widely assumed to be causally involved in the etiology of obesity, and underlie public health messages globally. Key non-nutrition prevention targets are increases in physical activity and reductions in time spent in sedentary behavior. ${ }^{3}$ Public health approaches to the obesity epidemic that targets these areas show promise in the prevention of childhood

${ }^{*}$ Correspondence: A Must, Department of Public Health and Family Medicine, Tufts University School of Medicine, 136 Harrison Avenue, Boston, MA 02111, USA.

E-mail: Aviva.must@tufts.edu obesity, as summarized in another paper at this conference (B Sherry, in this issue). Although logic models can provide support for community-based interventions, evidence-based approaches are favored. Several intervention studies have evaluated the impact of increased physical activity or decreased sedentary behavior as part of multifactorial interventions on prevention of weight/fatness gains or remission of overweight in clinical and community-based settings, with mixed results. ${ }^{4-9}$ One small pilot study that focused only on decreasing sedentary behavior yielded significant results, ${ }^{10}$ providing experimental evidence that sedentary behavior is causally linked to overweight. After briefly summarizing select cross-sectional studies, we review prospective research on the role of physical activity and inactivity in the development of obesity or increased relative weight, in children and adolescents, and highlight some of the methodological challenges and limitations in the literature to date. 


\section{Physical activity}

Energy expenditure, physical activity, and fitness are terms often used interchangeably, despite important distinctions among these constructs. ${ }^{11}$ Physical activity occurs over four dimensions: frequency (\#sessions/unit time), intensity (rate of energy expenditure, adjusted for body size), time, and type (a qualitative descriptor). Physical activity is not equivalent to activity energy expenditure; rather, energy expenditure is the result of physical activity. Total energy expenditure is comprised of several components: resting energy expenditure, the thermic effect of food, activity energy expenditure, and, for children, the energy required for growth. When studying the link between physical activity and weight status, physical activity should be conceptualized as body movement, a behavior, not as energy expended. ${ }^{12}$ Physical fitness is a characteristic of individuals that relates to their ability to perform physical activity. Fitness has a strong inherited component, but is modifiable - within an individual's range - through training.

Most studies in the US suggest a secular trend toward declines in physical activity in youth over the past several decades. ${ }^{13,14}$ Furthermore, over the childhood period, physical activity appears to decline with increasing age. ${ }^{15-20}$ Also, the type of physical activity changes with growth and development. Free play or other nonsustained activities give way to more structured activities such as team sports, sports clubs, individual lessons (eg, dance, gymnastics, martial arts), and school-based physical education. ${ }^{21}$ Measurement methods may not adequately capture these developmental changes. We found that the age-related changes observed over adolescence in a small sample of girls were influenced by how activity was measured: activity energy expenditure (adjusted for fat-free mass) declined over adolescence, but relative energy expenditure, expressed as the physical activity level (PAL, defined as total energy expenditure/resting metabolic rate), increased over the same period. ${ }^{17}$ This observation emphasizes the need to consider definitional issues when evaluating studies in this area.

Measuring physical activity is challenging, particularly the physical activity of children. Several comprehensive reviews of the measurement of physical activity have been published. ${ }^{22-24}$ Objective measures of physical activity include accelerometers, heart rate monitors, pedometers, and direct observation. Disadvantages of these measures, in general, include high cost and altered behavior due to measurement. In particular, heart rate monitors have limited utility because other factors influence heart rate independent of physical activity: psychological state and temperature, for example. The drawbacks of pedometers include their limitation to walking-type activities, their weak to moderate correlation with accelerometry, and their lack of information on activity intensity. Accelerometers, which have improved in terms of capturing movement in three dimensions, remain expensive. All of these devices require the subject (or caregiver) to remember to put it on each day and after bathing. ${ }^{25}$ These issues limit the use of objective measures in most longitudinal settings.

In the larger studies undertaken to observe change in weight and/or fatness, self- or proxy-report of physical activity is the most practical option. A website compiled by Sallis provides more than 20 of the surveys and measures commonly used to assess physical activity (www.drjamessallis. sdsu.edu/measures.html). Although collection of physical activity information via questionnaires or interviews can lead to bias or misclassification of exposure, they can yield valid estimates of the total amount of physical activity. $^{26}$ In addition, because young children are often not able to accurately report their own behavior, most studies of young children rely on proxy reports from parents or other individuals with direct contact with youth (eg, teachers, childcare providers). The majority of the studies reviewed here queried the frequency, intensity, and/or type of physical activity. Other potentially important aspects of physical activity, such as temperament and fidgeting, may not be captured by objective or self-report measures. $^{27,28}$

\section{Inactivity/sedentary behavior}

In contrast to physical activity, inactivity occurs when body movement is minimal, ${ }^{29}$ and can be defined as the amount of time spent in sedentary behavior. Sedentary behavior, like physical activity, can be considered over multiple dimensions: time (amount of time spent in inactivity) and type. By definition, sedentary behaviors are of low intensity; attempts to identify energy expenditure differences among distinct types of sedentary behavior have yielded mixed results. ${ }^{30,31}$ Types of sedentary activities include television viewing, reading, working at a computer, or talking with friends on the telephone while sitting. ${ }^{32}$

Parallel to declines in physical activity with age and over time has been the emergence of electronic media in the lives of children. The amount of leisure inactivity increases in US children from ages 14 to $20 \mathrm{y} .{ }^{19}$ Families with children are among the fastest growing population groups using the Internet, with estimates that $58 \%$ of US residents access the Internet from their homes in 2002. ${ }^{33}$ With dramatic increases in TV and computer ownership documented in developing countries, it is likely that similar increases in sedentary behavior will be seen there as well. ${ }^{34}$

Like physical activity, inactivity/sedentary behavior can be measured by objective measures as well as by self- or proxyreport. By their nature, objective measures consider inactivity as the 'low end' of the physical activity continuum. For example, subjects in the Framingham Children's Study were categorized as 'inactive', based on being below the median by accelerometry. $^{35}$ In contrast, physical activity and sedentary behavior can be approached as separate constructs, 
reflecting the notion that inactivity is not merely the opposite of activity, ${ }^{29}$ and that the type of sedentary behavior (ie, how a child is inactive) will have specific impact. Sedentary behavior is commonly measured by surveys with items designed to capture time spent in lowactivity pursuits, as well as the type of activity, by self- or proxy-report. These assessments, like those for physical activity, are not without error. For example, although it had been reported that parental report of $\mathrm{TV}$ viewing correlates well with observed patterns, ${ }^{36}$ in-home videotape observations confirm the imprecision of parent and child report of time spent viewing the television. ${ }^{37}$

Television viewing is the most frequently surveyed type of sedentary behavior in children, but many other activities besides TV viewing contribute. ${ }^{38}$ These sedentary behaviors change over childhood, and range from 'stroller time,' to time sitting in the classroom at school, doing homework, listening to music, surfing the Internet, talking on the phone, or reading. Screen time, which refers to time spent watching television or videos, playing video games, and working at the computer, represents a major source of inactivity that changes over childhood and adolescence. Whereas television and video viewing dominate during early and mid-childhood, other screens become more prominent during adolescence. Increasingly, people, particularly youth, do many things simultaneously. One quarter of American children report that they use another form of media 'most of the time' while watching TV; similarly, one-third of children report such multi-tasking behavior when using the computer. ${ }^{39}$ In addition, the proportion of time that children are focused on the screen when they are watching TV is highly variable. ${ }^{37,40}$ Further, measuring only the amount of time spent watching TV does not consider important variables such as the type of TV shows, exposure to food advertisement, whether the child was watching with parents, and the child's cognitive stimulation. ${ }^{41}$

The lines between types of sedentary behaviors themselves are being blurred, with the growing saturation of cell phones with built-in games, and video game systems with 'live' networks that permit chat over world-wide, multi-player networks. The increasing number of product placements in video games (eg, fast-food restaurants) may necessitate a rethinking of the relative importance of different mechanisms through which these different sedentary behaviors bring about overweight (A reduction in activity? Advertisements? A context for encouraging overeating and snacking?). The extent to which these behaviors are 'sedentary' is changing as well. With communication by telephone often by cellular phone, it is as likely to occur while walking as while sitting. Video game systems are becoming ever more portable; so although this feature ostensibly presents opportunities for physical activity (such as walking) while playing the games; such portability may encourage more sedentary behavior in settings traditionally thought of as physical activity-promoting, such as parks, playgrounds, school recess, etc.

\section{Weight status and adiposity}

Most of the studies reviewed rely on body mass index (BMI = weight in $\mathrm{kg}$ /square of height in meters), or on a measure that is based on BMI, to reflect weight status or adiposity. Although BMI does not differentiate between muscle and fat, it correlates with more direct measures of fatness, ${ }^{42}$ and is linked to both short- and long-term health outcomes in children. ${ }^{43-45}$ In children, BMI is often expressed as BMI $Z$-score, calculated relative to reference data to account for changes with age, and differences by sex. ${ }^{46,47}$ At risk of overweight, overweight, and obesity - terminology that varies with the reference data set used-are categorical measures derived from BMI $Z$-score, and are defined at the 85 th and 95 th percentiles. ${ }^{46,47}$ Seven of the 20 studies reviewed here use more direct and precise measures of adiposity, such as single or multiple skinfold thicknesses, dual-energy X-ray absorptiometry, or percent body fat by BIA.

\section{Physical activity and the development of obesity Summary of cross-sectional studies}

Most investigations of the role of physical activity and sedentary behavior in the development of obesity have been cross-sectional. In our review of these studies, we found, like others, ${ }^{48}$ that most cross-sectional studies reported that overweight children had lower PALs than their non-overweight peers. ${ }^{49-52}$ Some of these studies include objective measures of physical activity, such as accelerometer data. ${ }^{53-55}$ Null findings are not uncommon. ${ }^{56,57}$ One study found that obese youth are more active than nonobese youth. ${ }^{58}$ Two recent cross-sectional studies, however, illustrate the variety of findings: BMI was negatively associated with physical activity in females, but not males, ${ }^{59}$ whereas fat mass was negatively associated with physical activity in males, but not females. ${ }^{60}$

Cross-sectional studies in this area, however, do not allow determination of cause and effect because physical activity can be both an antecedent and consequence of obesity. ${ }^{61}$ Children who are already overweight may have lower levels of physical activity as a consequence of their weight status. Particularly in childhood, when physical activity often occurs as part of organized sport, overweight children may be less likely to want to participate, either due to fears of teasing or being ostracized, or because they are 'less athletic.' Direct social support as well as self-efficacy have been shown to be important predictors of participation in physical activity for youth. ${ }^{62}$ The high rates of peer victimization identified among overweight youth ${ }^{63}$ may result in reduced participation in sports. Faith found that children who are criticized for their weight by their parents or by other children are less likely to enjoy sports, and less likely to participate in mild-intensity leisure activity. ${ }^{64}$ Thus, plausible mechanisms exist for reverse causation in the relation of physical activity and weight status. 
Summary of prospective observational studies

Table 1 summarizes 17 studies on 16 cohorts. Only five of the studies used objective measures of physical activity. ${ }^{35,48,65-67}$ The others relied on self-reported measures, either by the children themselves, ${ }^{61,68-71}$ by their parents, ${ }^{72-77}$ or by a combination thereof. ${ }^{78}$ In the Framingham Children's Study, children wore accelerometers for up to 5 days twice per year. In an early report based on $1 \mathrm{y}$ of follow-up during the preschool years, changes in adiposity were smaller with higher levels of activity; ${ }^{35}$ the 8 -y follow-up results were extended, and the outcomes expanded to include BMI, ${ }^{48}$ with results consistent with the earlier report. Among Native American second-grade children in the Pathways Project, activity based on accelerometry was associated with lower adiposity among children of normal weight status, but with higher adiposity and BMI among overweight children. ${ }^{65}$ In 3-4-y-old children from Texas, heart rate telemetry from multiple days was used to assess physical activity over $3 \mathrm{y}$. Repeated-measures regression analysis showed that physical activity was positively associated with BMI in year 1 of follow-up, but negatively associated in years 2 and $3,{ }^{66}$ an interaction which the researchers interpreted as developmental differences emerging at age 6-7. Kettaneh et al ${ }^{67}$ used 7 days of data from pedometers to classify French children as having low or high activity levels. There were no differences between the groups in adiposity measures at follow-up (BMI, percent body fat, waist circumference, and sum of skinfolds), after adjusting for baseline adiposity, Tanner stage, and age. $^{67}$

Of publications that relied on reported physical activity, five were studies of children reporting on their own activity. Some studies converted activity data to estimated metabolic equivalents (METS), whereas others used activity time or report of sports participation. The 10769 early adolescents studied over $1 \mathrm{y}$ as part of the Growing Up Today Study (GUTS) completed a youth activity questionnaire. Physical activity, expressed as METS derived from activity items, was inversely related to change in selfreported BMI in girls, adjusting for baseline BMI; similar results in boys were of borderline significance. ${ }^{69}$ The nationally representative sample of 12759 US youth in the National Longitudinal Study of Adolescent Health also used physical activity recall data converted to METS. Each additional bout of moderate to vigorous activity per week was associated with lower odds of becoming overweight. ${ }^{70}$ In contrast, no association between incident overweight (based on measured height and weight) and estimated METs was seen in a 4-y follow-up of 496 girls aged $11-15 y$ from the Past Year Leisure PA Scale. ${ }^{71}$ Time spent in exercise assessed $4 \mathrm{y}$ earlier was inversely related to BMI in Welsh adolescents. ${ }^{61}$ Follow-up data (1- and 2-y) on a large cohort of lowincome children (mean age $\sim 10 \mathrm{y}$ ) in Montreal found that for boys, high physical activity (based on an adaptation of a validated 7-day physical activity recall) and participation in sports outside of school were related to less excess weight gain over $2 \mathrm{y}$, but not over $1 \mathrm{y}$. For girls, sports outside of school were related to less excess weight gain over $1 \mathrm{y}$, but not over $2 \mathrm{y}^{68}$ Also, a noteworthy study from the Netherlands of older children (not summarized in Table 1 because follow-up was into adulthood) demonstrated that physical activity in 13-y-old children was inversely related to fat mass over the next $20 \mathrm{y}$, as measured longitudinally by the sum of four skinfolds. ${ }^{79}$

Finally, the activity literature includes seven studies that utilized parent report of child activity. ${ }^{72-78}$ The children in these studies tended to be young; all but Maffeis et al's study of elementary school-aged children was conducted on children aged 9 or younger. With the exception of the studies by Klesges $^{72}$ and Horn, ${ }^{78}$ no significant associations between parent-reported physical activity and weight or fatness measures were demonstrated. In the study by Klesges et $a l,{ }^{56}$ baseline aerobic activity level relative to peers was inversely related to change in BMI over $2 y$, but structured physical activity and leisure time physical activity were not significantly related to BMI change. In Mohawk children followed up $2 \mathrm{y}$ after a baseline measure, physical activity in girls was positively related to adiposity increases, as measured by sum of skinfolds; ${ }^{78}$ this study included a mix of parental report (children grades 1-3) and self-report (grades 4-6).

\section{Physical inactivity and the development of obesity Summary of cross-sectional studies}

Dietz noted, $10 \mathrm{y}$ ago, that although the adverse effects of sedentary behavior might be as important as the positive effects of vigorous physical activity, the former had received far less attention. ${ }^{29}$ The extant literature on the role of sedentary behavior in the development of obesity is still less well-developed in comparison to physical activity. Most of the studies examining this relationship have been crosssectional. For example, in Mexican children aged 9-16, the odds ratio for prevalence of overweight was 1.12, with each additional hour per day of TV. ${ }^{80}$ In a study of Swiss children, each additional hour of video games played daily was associated with a doubling of obesity risk. ${ }^{38}$ Similar significant relationships between sedentary behavior (usually TV) and increased adiposity have been seen cross-sectionally, ${ }^{41,59,80-88}$ with some suggestion that the relationship is getting stronger over time. ${ }^{81}$ In a study of Australian children, however, after adjusting for covariates, there was no relationship between obesity and time spent with TV, video games, or computers. ${ }^{89}$ Such null findings are also common. ${ }^{40,57,90,91}$ We found two case-control studies in our review of the literature, which were essentially crosssectional in design. Television was significantly related to obesity in a case-control study of 223 obese 7-10-y-old children and controls in Sao Paulo. ${ }^{92}$ Children who watched TV for more than $4 \mathrm{~h}$ a day were twice as likely to be obese. Similar results were seen in obese 5 -y-old French children, compared to their peers. ${ }^{93}$ A meta-analysis of 39 studies (mostly cross-sectional) of sedentary behavior and obesity 
Table 1 Longitudinal studies investigating the role of physical activity on the development of obesity in youth

\begin{tabular}{|c|c|c|c|c|c|c|}
\hline Reference & Study design & $\begin{array}{l}\text { Characteristics of } \\
\text { study participants }\end{array}$ & Assessment of physical activity & Statistical analysis & Outcome measures & Main findings \\
\hline Berkey, $2000^{69}$ & Pre-post $1 \mathrm{y}$ & $\begin{array}{l}10769 \text { US children } \\
9-14 y \text { at baseline }\end{array}$ & $\begin{array}{l}\text { Self-report Youth Activity } \\
\text { Questionnaire converted to } \\
\text { total METs/week outside of } \\
\text { school, PE classes/week }\end{array}$ & $\begin{array}{l}\text { MLR adjusted for race, baseline } \\
\text { BMI, change in height, and } \\
\text { Tanner stage }\end{array}$ & Self-report BMI by mail & $\begin{array}{l}\mathrm{PA} \text { inverse in girls }-0.284 \mathrm{~kg} / \\
\mathrm{m}^{2} / \mathrm{h} / \text { day PA borderline } \\
\text { significance in boys }\end{array}$ \\
\hline Bogaert, $2003^{76}$ & Pre-post 1 y & $\begin{array}{l}41 \text { Australian } \\
\text { children } 6-9 y \text { at } \\
\text { baseline }\end{array}$ & $\begin{array}{l}\text { Parental report of hours of } \\
\text { planned exercise, percent time } \\
\text { in activities of various } \\
\text { intensities }\end{array}$ & Partial correlations & BMI $z$-score by measured $\mathrm{ht} / \mathrm{wt}$ & NS \\
\hline Burke, $2005^{77}$ & Pre-post $2 y$ & $\begin{array}{l}1430 \text { Australians } \\
\text { (Western Australia } \\
\text { Pregnancy } \\
\text { Cohort), age 6y at } \\
\text { baseline }\end{array}$ & $\begin{array}{l}\text { Parental report of outdoor } \\
\text { play, involvement in organized } \\
\text { sport }\end{array}$ & $\begin{array}{l}\text { MLR with backward selection. } \\
\text { Adjusted for parental BMI, } \\
\text { birthweight, maternal } \\
\text { smoking, TV at baseline, } \\
\text { activity at follow-up (not } \\
\text { baseline BMI) } \\
\text { Logistic regression with same } \\
\text { predictors }\end{array}$ & $\begin{array}{l}\text { BMI measured height/weight } \\
\text { Overweight/obesity }\end{array}$ & NS \\
\hline Davison, $2001^{74}$ & Pre-post $2 y$ & $\begin{array}{l}197 \text { White girls, } \\
\text { age } 5 y \text { at baseline }\end{array}$ & $\begin{array}{l}\text { Maternal ranking of PA level } \\
\text { relative to peers. Girls' } \\
\text { preference for PA measured at } \\
\text { age } 7 y\end{array}$ & $\begin{array}{l}\text { Hierarchical MLR for change in } \\
\text { BMI, adj. for baseline BMI and } \\
\text { parental education }\end{array}$ & BMI by measured $\mathrm{ht} / \mathrm{wt}$ & NS \\
\hline $\begin{array}{l}\text { Gordon-Larsen, } \\
2002^{70}\end{array}$ & Pre-post 1 y & $\begin{array}{l}12759 \text { nationally } \\
\text { representative US } \\
\text { children age } 12- \\
22 \text { y }\end{array}$ & Physical activity recall & $\begin{array}{l}\text { Logistic regression for }>95 \text { th } \\
\text { BMl, adjusted for age, } \\
\text { ethnicity, SES, urban, smoking, } \\
\text { and region }\end{array}$ & BMI by measured ht/wt & $\begin{array}{l}\text { Boys: OR for overweight } 0.86 \\
\text { with additional moderate to } \\
\text { vigorous PA bout/week } \\
\text { Girls: OR for overweight } 0.90 \\
\text { with additional moderate to } \\
\text { vigorous PA bout/week }\end{array}$ \\
\hline Horn, $2001^{78}$ & Pre-post $2 y$ & $\begin{array}{l}198 \text { Mohawk } \\
\text { children in Quebec } \\
\text { elementary } \\
\text { schools, age } 7.5 y \\
\text { at baseline }\end{array}$ & $\begin{array}{l}\text { Grades } 1-3 \text {, questionnaire with } \\
\text { parents. Grades } 4-6 \text {, self- } \\
\text { report PA by Weekly Activity } \\
\text { Checklist, converted to METs }\end{array}$ & $\begin{array}{l}\text { Stepwise MLR predicting } \\
\text { subscapular skinfolds from } \\
\text { baseline skinfolds and age and } \\
\text { sex }\end{array}$ & Subscapular skinfold thickness & $\begin{array}{l}\text { Girls: higher PA levels positively } \\
\text { related to follow-up SSF }\end{array}$ \\
\hline Jago, $2005^{66}$ & $y 1, y 2, y 3$ & $\begin{array}{l}138 \text { US children } \\
\text { age } 3-4 y \text { at } \\
\text { baseline } \\
37 \% \text { White, } 37 \% \\
\text { Black, } 26 \% \\
\text { Hispanic }\end{array}$ & $\begin{array}{l}\text { Heart rate telemetry: } 3 \text { or } 4 \\
\text { days } \\
\text { Observed and rated with } \\
\text { Children's Activity Rating Scale } \\
\text { (levels } 1 \text { and } 2 \text { deemed } \\
\text { sedentary) }\end{array}$ & $\begin{array}{l}\text { Repeated-measures regression } \\
\text { with BMI as outcome. Stepwise } \\
\text { backward deletion. } \\
\text { Independent variables: TV, } \\
\text { sedentary behavior, PA, diet, } \\
\text { ethnicity, gender, year, } \\
\text { baseline BMI, interactions }\end{array}$ & BMI by measured ht/wt & $\begin{array}{l}\text { Inverse relation between PA } \\
\text { and BMI, strength increases } \\
\text { with age }\end{array}$ \\
\hline Kettaneh, $2005^{67}$ & Pre-post $2 y$ & $\begin{array}{l}436 \text { French non- } \\
\text { obese (Fleurbaix- } \\
\text { Laventie Ville Sante } \\
\text { II Study), 8-18y at } \\
\text { baseline }\end{array}$ & $\begin{array}{l}\text { Pedometer worn for } 7 \text { days at } \\
\text { baseline } \\
\text { Self-report Modifiable Activity } \\
\text { Questionnaire (MAQ) for h/ } \\
\text { week in leisure-time PA }\end{array}$ & $\begin{array}{l}\text { MLR predicting adiposity, } \\
\text { adjusting for baseline } \\
\text { adiposity, Tanner, and age }\end{array}$ & $\begin{array}{l}\text { BMI by measured ht/wt } \\
\text { BIA } \\
\text { Sum of four skinfolds, waist } \\
\text { circumference }\end{array}$ & $\begin{array}{l}\text { Pedometer data NS } \\
\text { For MAQ, in girls only, higher } \\
\text { levels of moderate activity } \\
\text { associated with higher } \\
\text { adiposity at follow-up }\end{array}$ \\
\hline Klesges, $1995^{72}$ & Pre-post $3 y$ & $\begin{array}{l}146 \text { Tennessee }^{14} \\
4.4 y \text { at baseline }\end{array}$ & $\begin{array}{l}\text { Parental report; Likert scale for } \\
\text { structured and aerobic activity }\end{array}$ & $\begin{array}{l}\text { MLR, adjusted for many } \\
\text { variables. Both baseline and }\end{array}$ & BMI change & $\begin{array}{l}\text { Higher baseline aerobic activity } \\
\text { predicted decrease in BMI }\end{array}$ \\
\hline
\end{tabular}




\begin{tabular}{|c|c|c|c|c|c|c|}
\hline Reference & Study design & $\begin{array}{l}\text { Characteristics of } \\
\text { study participants }\end{array}$ & Assessment of physical activity & Statistical analysis & Outcome measures & Main findings \\
\hline Maffeis, $1998^{73}$ & Pre-post $4 y$ & $\begin{array}{l}112 \text { White Italians, } \\
8.6 y \text { at baseline }\end{array}$ & $\begin{array}{l}\text { Parental report of } \mathrm{min} / \text { day in } \\
\text { extra-curricular physical } \\
\text { exercise or vigorous play for } \\
\text { activity index }\end{array}$ & $\begin{array}{l}\text { MLR adjusted for age, sex, El, } \\
\text { \%protein, \%fat, } \\
\text { \%carbohydrates, parental BMI, } \\
\text { inactivity }\end{array}$ & $\begin{array}{l}\text { Obesity as relative } \mathrm{BMI} \\
>120 \% \text {, measured ht/wt }\end{array}$ & $\begin{array}{l}\text { NS for prediction of change in } \\
\text { relative BMI }\end{array}$ \\
\hline Moore, $1995^{35}$ & Pre-post 1 y & $\begin{array}{l}97 \text { US } \\
\text { (Framingham } \\
\text { Children's Study, } \\
\text { US), mean age } 4 y \\
\text { at baseline }\end{array}$ & $\begin{array}{l}\text { Accelerometer twice/y, } 5 \\
\text { consecutive days - counts per } \\
\text { hour. 'active' above median. } \\
\sim 230 \text { h per child }\end{array}$ & $\begin{array}{l}\text { Multiple Logistic - outcome } \\
\text { increasing anthropometry, adj } \\
\text { age, sex, TV, Harter's, El from } \\
\text { diet record, parental BMI }\end{array}$ & $\begin{array}{l}\text { Change in Triceps SF for body } \\
\text { fatness (also looked at } \\
\text { subscapular and BMI) }\end{array}$ & $\begin{array}{l}\text { Active girls gained } 1 \mathrm{~mm} \text { in } \\
\text { TSF, inactive girls } 1.75 \mathrm{~mm} \text {. } \\
\text { Active boys lost } 0.75 \mathrm{~mm} \text {, } \\
\text { inactive gained } 0.25 \mathrm{~mm} \text { TSF. } \\
\text { Adjusted OR: in leaner youth, } \\
\text { NS risk for low activity; in } \\
\text { heavier youth, OR }=5.8 \text {. } \\
\text { Elevated risk of increasing TSF } \\
\text { if inactive }\end{array}$ \\
\hline Moore, $2003^{48}$ & $\begin{array}{l}\text { Baseline and } 7 y \text { of } \\
\text { follow-up }\end{array}$ & $\begin{array}{l}103 \text { US } \\
\text { (Framingham } \\
\text { Children's Study), } \\
\text { mean age } 4 y\end{array}$ & $\begin{array}{l}\text { Accelerometer once or twice a } \\
\text { year, } 3-5 \text { days }\end{array}$ & $\begin{array}{l}\text { Mixed model controlling for } \\
\text { sex, age, baseline BMI, TV } \\
\text { hours per day, \% kcal fat, } \\
\text { parental education and } \\
\text { parental BMI }\end{array}$ & $\begin{array}{l}\text { BMI by measured height and } \\
\text { weight, triceps skinfolds, sum } \\
\text { of skinfolds }\end{array}$ & $\begin{array}{l}\text { Most active children had } \\
\text { smaller gains in BMl, triceps } \\
\text { skinfold, and sums of skinfolds }\end{array}$ \\
\hline $\begin{array}{l}\text { O'Loughlin, } \\
2000^{68}\end{array}$ & Pre-post $2 y$ & $\begin{array}{l}\text { Multi-ethnic } \\
\text { Montreal low SES } \\
n=2001 \text { for } 1-y \\
\text { changes } \\
n=633 \text { for } 2-y \\
\text { changes } \\
\sim 10 \text { at baseline }\end{array}$ & $\begin{array}{l}\text { Self-report 7-day PA recall, } \\
\text { converted to } 0 \text { - } 105 \text { frequency } \\
\text { score; sports team } \\
\text { participation; sports outside } \\
\text { school }\end{array}$ & $\begin{array}{l}\text { Logistic for 'excess weight } \\
\text { gain,' adjusted for baseline BMI }\end{array}$ & $\begin{array}{l}\text { BMI by measured height and } \\
\text { weight - excess weight gain as } \\
\text { change in BMI > 90th } \\
\text { percentile change in BMI for } \\
\text { same age, same sex in } \\
\text { population }\end{array}$ & $\begin{array}{l}\text { Boys } 2 \text { y: PA frequency and } \\
\text { outside school sports } \\
\text { significant; girls } 1 \text { y: outside } \\
\text { school sports significant }\end{array}$ \\
\hline Salbe, $2002^{75}$ & Pre-post $5 y$ & $\begin{array}{l}138 \text { Pima Indians, } \\
5 y \text { at baseline }\end{array}$ & $\begin{array}{l}\text { Parent report of about type } \\
\text { and time in sport and } \\
\text { recreation }\end{array}$ & $\begin{array}{l}\text { MLR, adjusted for baseline } \\
\text { body composition }\end{array}$ & Body comp from ${ }^{18} \mathrm{O} / \mathrm{DXA}$ & $\begin{array}{l}\text { NS for physical activity } \\
\text { measures }\end{array}$ \\
\hline Stevens, $2004^{65}$ & Pre-post $3 y$ & $\begin{array}{l}454 \text { second grade } \\
(7.5 y) \text { at baseline, } \\
\text { Amer. Indian }\end{array}$ & $\begin{array}{l}\text { Accelerometer (AVM), } 1 \text { school } \\
\text { day at baseline }\end{array}$ & $\begin{array}{l}\text { MLR adjusted baseline body } \\
\text { composition, sex, height, } \\
\text { change in height }\end{array}$ & $\begin{array}{l}\text { Four outcomes: measured BMI, } \\
\text { FM, FFM and \%body fat by } \\
\text { BIA, eth-specific equation }\end{array}$ & $\begin{array}{l}\text { In normal weight kids, AVM } \\
\text { with lower } \% \text { bfat. } \\
\text { Overweight kids, AVM with } \\
\text { higher BMI, fat mass, and FFM }\end{array}$ \\
\hline Stice, $2005^{71}$ & $\begin{array}{l}\text { Baseline and four } \\
\text { annual follow-ups }\end{array}$ & $\begin{array}{l}496 \text { US girls, } 11- \\
15 y \text { at baseline, } \\
68 \% \text { White }\end{array}$ & $\begin{array}{l}\text { Self-report Past Year Leisure } \\
\text { Physical Activity Scale with } \\
\text { METs }\end{array}$ & $\begin{array}{l}\text { Logistic regression: baseline } \\
\text { factors predict onset of obesity } \\
\text { in nonobese }\end{array}$ & $\begin{array}{l}\text { BMl by measured ht/wt } \\
\text { Obesity }>95 \text { th }\end{array}$ & NS \\
\hline
\end{tabular}

$\mathrm{PA}=$ physical activity, $\mathrm{PE}=$ physical education, $\mathrm{MLR}=$ multiple linear regression, $\mathrm{AVM}=$ average vector magnitude, $\mathrm{ht}=$ height, $\mathrm{wt}=$ weight, $\mathrm{FM}=$ fat mass, $\mathrm{FFM}=$ fat-free mass, $\mathrm{OR}=$ odds ratio, $\mathrm{SES}=$ socioeconomic status, $\mathrm{NS}=$ not statistically significant, ${ }^{18} \mathrm{O}={ }^{18} \mathrm{O}$ dilution, $\mathrm{DXA}=$ dual-energy $\mathrm{X}$-ray absorptionmetry. 
yielded a statistically significant, although small, effect size. $^{94}$

As with cross-sectional studies on physical activity and development of obesity, the cross-sectional design also limits the determination of cause and effect for sedentary behavior. Perhaps children watch more TV because their obesity makes it more difficult to exercise due to physical limitations, or due to social isolation; compared to normal-weight adolescents, overweight adolescents have fewer friends and are more likely to have no friends, as assessed by friendship 'nominations' by peers. ${ }^{95}$

\section{Summary of prospective observational studies}

Table 2 summarizes 15 prospective observational studies on the role of inactivity and or sedentary behavior in the development of overweight. Nine of the studies focused on children younger than age 10 . $^{66,73,75-78,81,96,97}$ Of the studies with younger subjects, most reported positive associations between television viewing and adiposity. ${ }^{66,77,78,81,96,97}$

Each additional hour of TV watched by Australian children at age 6 was associated with a $40 \%$ increased odds of overweight at age 8 . Associations remained significant after adjusting for birth weight, maternal BMI, maternal smoking, and children's PAL. ${ }^{77}$ Similarly, in the aforementioned Framingham Children's Study, TV and video-viewing habits were assessed during eight annual study cycles. Of the 103 children in the study, those with the largest increases in skinfolds were the children who had watched the most TV. ${ }^{97}$ A positive relationship between television and BMI was also seen in preschool (3-4y) children followed for $3 \mathrm{y} .{ }^{66}$ Horn et $a l^{78}$ reported a significant relationship between TV and adiposity in girls, but not boys; Mohawk girls (age 7.5) who watched $>4.5 \mathrm{~h} /$ week of TV had graded increases in subscapular skinfold thickness over $2 y$. Finally, in a study of young US children (age $5 \mathrm{y}$ ), those who watched more TV had higher BMI at age 9, but only if they were from families with no overweight parents. ${ }^{96}$

We reviewed two smaller studies of young children that did not support these positive findings between sedentary behavior and obesity. Null relationships were reported between change in BMI $Z$-score and TV viewing in 41 Australian children age $6-9 \mathrm{y}$ followed for $1 \mathrm{y},{ }^{76}$ and similarly between change in percent body fat and hours of sedentary behavior in 138 Pima Indian children assessed at age 5 and again at age $10 .^{75}$

In contrast to studies of younger children, only two studies that we reviewed consistently found a significant relationship between sedentary behaviors and development of obesity in older children; ${ }^{70,81}$ most studies reported null findings. In a nationally representative sample of US children (age 12-22y), TV and video game use predicted higher odds of obesity $1 \mathrm{y}$ later. The odds ratio for boys was 1.49 with $>35 \mathrm{~h}$ of TV/video per week; for girls, the OR was $1.43 .^{70}$ In another nationally representative sample of
American children assessed at ages $10-15 \mathrm{y}$, baseline TV viewing was a significant predictor of overweight $4 \mathrm{y}$ later. $^{81}$ We identified two other studies with mixed results - one reported significant results in boys, ${ }^{69}$ whereas the other reported a relationship only in girls. ${ }^{68}$ In US boys aged 9-14, sedentary behavior-again, measured by TV viewing time - was related to BMI 1 y later; however, the relationship was not seen in girls. ${ }^{69}$ Girls in Montreal who played more video games at age 10 were more likely to have excess weight gain over the next $2 y$ than their female peers who played less; in boys, however, the relationship was not seen. ${ }^{68}$

Most of the prospective studies in older children did not find a significant relationship between sedentary behavior and adiposity. In 335 Welsh children aged $12 \mathrm{y}$, self-reports of $\mathrm{h}$ /week of TV, videos, and computer were not related to BMI 4 y later, after adjustment for baseline values. ${ }^{61}$ Similar null results were reported by Robinson in US children, also aged 12 , who were followed up after $2 \mathrm{y}$; there was no relationship of TV viewing and change in BMI or change in skinfold thickness. ${ }^{90}$ Finally, two studies of children from continental Europe yielded null results: 112 Italians were measured at age 12 after a baseline visit 4 y earlier, ${ }^{73}$ and 436 French children $8-18 \mathrm{y}$ were assessed $2 \mathrm{y}$ after their baseline TV and video games were queried. ${ }^{67}$

\section{Methodologic challenges/statistical issues}

The studies reviewed here yield a wide range of results regarding the development of obesity in youth, with respect to both physical activity and sedentary behavior. Several methodologic challenges can explain not only the expected inverse relationships for physical activity and obesity, ${ }^{70}$ but also the expected positive relationships between sedentary behavior and obesity; ${ }^{97}$ the numerous null findings and even the occasional counterintuitive result. ${ }^{78}$ These challenges include measurement issues, sample selection, and statistical issues such as residual confounding, overadjustment, model selection, and inappropriate longitudinal analyses.

Physical activity and sedentary behaviors are difficult to measure in children; the myriad issues related to measurement have been reviewed elsewhere. ${ }^{22-24}$ Random error in measurement of exposure can lead to misclassification of status, typically biasing the observed relationship toward the null. Weak associations between sedentary behavior and obesity might be indicative of stronger effect sizes that are diluted by imprecise measurement. ${ }^{37}$ Thus, the choice of measurement device might affect the conclusions drawn; for example, cross-sectional studies of physical activity and adiposity that use motion counters yield greater effect size than questionnaires. ${ }^{12}$ Furthermore, nonrandom misclassification can bias the results in unexpected directions. In one study reviewed here, no relationship between the baseline measure of physical activity and subsequent adiposity was 
Table 2 Longitudinal studies investigating the role of sedentary behavior on the development of obesity in youth

\begin{tabular}{|c|c|c|c|c|c|c|}
\hline Reference & Study design & $\begin{array}{l}\text { Characteristics of } \\
\text { study participants }\end{array}$ & $\begin{array}{l}\text { Assessment of sedentary } \\
\text { behavior }\end{array}$ & Statistical analysis & Outcome measure & Main findings \\
\hline Berkey, $2000^{69}$ & Pre-post $1 y$ & $\begin{array}{l}10769 \text { US children } \\
9-14 y \text { at baseline }\end{array}$ & $\begin{array}{l}\text { Self-report of weekly hours of } \\
\text { TV, videos, and video/ } \\
\text { computer games }\end{array}$ & $\begin{array}{l}\text { MLR adjusted for race, baseline } \\
\text { BMI, change in height, and } \\
\text { Tanner stage }\end{array}$ & Self-report BMI by mail & TV significant in boys \\
\hline Bogaert, $2003^{76}$ & Pre-post $1 y$ & $\begin{array}{l}41 \text { Australian } \\
\text { children } 6-9 y \text { at } \\
\text { baseline }\end{array}$ & $\begin{array}{l}\text { Parental report of hours of TV } \\
\text { viewing }\end{array}$ & Partial correlations & BMI $z$-score by measured ht/wt & NS \\
\hline Burke, $2005^{77}$ & Pre-post $2 y$ & $\begin{array}{l}1430 \text { Australians } \\
\text { (Western Australia } \\
\text { Pregnancy } \\
\text { Cohort), age } 6 y \text { at } \\
\text { baseline }\end{array}$ & $\begin{array}{l}\text { Parental report of time } \\
\text { watching TV }\end{array}$ & $\begin{array}{l}\text { MLR with backward selection. } \\
\text { Adjusted for parental BMI, } \\
\text { birthweight, maternal } \\
\text { smoking, TV at baseline, } \\
\text { activity at follow-up (not } \\
\text { baseline BMI) } \\
\text { Logistic regression with same } \\
\text { predictors }\end{array}$ & $\begin{array}{l}\text { BMI measured ht/wt } \\
\text { Overweight/obesity }\end{array}$ & $\begin{array}{l}\text { TV borderline sig. for BMI at } \\
\text { follow-up. TV OR } 1.53(1.16 \text {, } \\
\text { 2.02) for overweight/obesity at } \\
\text { follow-up }\end{array}$ \\
\hline Elgar, $2005^{61}$ & Pre-post $4 y$ & $\begin{array}{l}335 \text { Welsh, } \\
\sim 12.3 y \text { at baseline }\end{array}$ & $\begin{array}{l}\text { Self-report of h/week TV, } \\
\text { video, computer }\end{array}$ & $\begin{array}{l}\text { MLR adjusted for sex, age, } \\
\text { baseline BMI, family size, SES } \\
\text { indicators, eating habits }\end{array}$ & $\begin{array}{l}\text { BMI by measured ht/wt } \\
\text { Overweight/obesity by } 85 \text { th } \\
\text { and } 95 \text { th of Cole }\end{array}$ & $\begin{array}{l}\text { NS after adjustment for } \\
\text { baseline BMI }\end{array}$ \\
\hline Francis, $2003^{96}$ & Pre-post $4 y$ & $\begin{array}{l}183 \text { White } \\
\text { American girls, age } \\
5 y \text { at baseline }\end{array}$ & $\begin{array}{l}\text { Parental report of hours of TV } \\
\text { viewing }\end{array}$ & $\begin{array}{l}\text { Path analysis, direct } \\
\text { relationship of TV on 4-y BMI } \\
\text { change }\end{array}$ & BMI by measured ht/wt & $\begin{array}{l}\text { TV significant predictor of age } \\
9 \text { BMl only in families with no } \\
\text { overweight parents }\end{array}$ \\
\hline Gortmaker, $1996^{81}$ & Pre-post $4 y$ & $\begin{array}{l}746 \text { nationally } \\
\text { representative US } \\
\text { children, age } \\
6-11 \text { y at baseline }\end{array}$ & $\begin{array}{l}\text { Parental report of hours of TV/ } \\
\text { day }\end{array}$ & $\begin{array}{l}\text { Logistic regression for } 85 \text { th } \\
\text { percentile BMI, adjusted for } \\
\text { confounders }\end{array}$ & BMI by measured ht/wt & $\begin{array}{l}\text { TV significant predictor of odds } \\
\text { of overweight }\end{array}$ \\
\hline Horn, $2001^{78}$ & Pre-post $2 y$ & $\begin{array}{l}198 \text { Mohawk } \\
\text { children in Quebec } \\
\text { elementary } \\
\text { schools, age } 7.5 y \\
\text { at baseline }\end{array}$ & $\begin{array}{l}\text { Grades } 1-3 \text {, questionnaire with } \\
\text { parents. Grades } 4-6 \text {, self- } \\
\text { report } \\
>4.5 \mathrm{TV} \text { h/week deemed } \\
\text { 'excessive watchers' }\end{array}$ & $\begin{array}{l}\text { Stepwise MLR predicting } \\
\text { subscapular skinfolds from } \\
\text { baseline skinfolds and age and } \\
\text { sex }\end{array}$ & Subscapular skinfold thickness & $\begin{array}{l}\text { Girls: excessive TV, positively } \\
\text { related to follow-up } \\
\text { subscapular skinfold }\end{array}$ \\
\hline Jago, $2005^{66}$ & $y 1, y 2, y 3$ & $\begin{array}{l}138 \text { US children } \\
\text { age } 3-4 y \text { at } \\
\text { baseline } 37 \% \\
\text { White, } 37 \% \text { Black, } \\
26 \% \text { Hispanic }\end{array}$ & $\begin{array}{l}\text { Observed and rated with } \\
\text { Children's Activity Rating Scale } \\
\text { (levels } 1 \text { and } 2 \text { deemed } \\
\text { sedentary beh.); TV also } \\
\text { recorded }\end{array}$ & $\begin{array}{l}\text { Repeated-measures regression } \\
\text { with BMI as outcome } \\
\text { independent variables: TV, } \\
\text { sedentary behavior, PA, diet, } \\
\text { ethnicity, gender, year, } \\
\text { baseline BMI, interactions. } \\
\text { Stepwise backward deletion }\end{array}$ & $\begin{array}{l}\text { BMI by measured height and } \\
\text { weight }\end{array}$ & $\begin{array}{l}\text { Direct relation between TV } \\
\text { viewing and BMl, strength } \\
\text { increases with age }\end{array}$ \\
\hline Maffeis, $1998^{73}$ & Pre-post $4 y$ & $\begin{array}{l}112 \text { White Italians, } \\
8.6 y \text { at baseline }\end{array}$ & $\begin{array}{l}\text { Parental report of in/day TV for } \\
\text { inactivity }\end{array}$ & $\begin{array}{l}\text { MLR adjusted for age, sex, El, } \\
\text { \%protein, \%fat, } \\
\text { \%carbohydrates, parental BMI, } \\
\text { and activity }\end{array}$ & $\begin{array}{l}\text { Obesity as relative } \mathrm{BMI} \\
>120 \% \text {, measured ht/wt }\end{array}$ & $\begin{array}{l}\text { NS for prediction of change in } \\
\text { relative BMI }\end{array}$ \\
\hline
\end{tabular}


seen when accelerometry was used to assess physical activity. But when self-report of physical activity was used, girls who reported more activity reported higher adiposity at follow-up, by all four measures of body composition. ${ }^{67}$

Sample selection is also crucial, for many reasons. As overweight develops due to small caloric imbalances over time, it is likely that researchers are trying to identify relatively small effects. Given these modest effect sizes, a relatively large sample is required for power to be adequate to detect statistically significant relationships. This could explain the null findings, especially in studies with the smallest samples. ${ }^{76}$ A large sample size is also needed to examine possible interactions, such as that between physical activity and initial body fat status, or between physical activity and gender. Without an adequate number of subjects, stratification limits the power of the analysis to detect significant differences. Consideration of effect modification is important because of the host of factors known to influence the development of obesity. Indeed, some researchers have cited the need for complex models that move beyond from simple bivariate relationships when exploring this research question. ${ }^{98}$ The age of the children in the sample also appears to be important. Berkey noted that activity and inactivity were more stable in older girls in their cohort; such lack of variability could make it difficult to determine whether a significant relationship exists.

Also challenging in the realm of activity behavior and obesity development are statistical issues related to covariates. Residual confounding has long been recognized as an issue; for example, sedentary behavior is correlated with other adverse health consequences such as increased fat intake. $^{29}$ To the extent that diet is imperfectly measured, confounding bias will remain, even with statistical control for fat intake. Another example is the considerable potential for residual confounding by socioeconomic status. Children with lower family incomes, with lower parental education, and non-white children tend to watch more TV than their peers. ${ }^{83,97,99}$ As the prevalence of overweight is higher among children of lower socioeconomic status and minority race/ethnicity, ${ }^{100}$ incomplete statistical control for these variables can obscure the true relationships. Such results are often found in cross-sectional studies as well; television viewing was related to overweight in 10-16-y olds, but was not significant after adjusting for ethnicity and socioeconomic status. ${ }^{57}$ Some models may be overadjusted. For example, parental obesity may influence opportunities for physical activity if overweight parents make extra efforts to counterbalance genetic inheritance. Consideration of the conceptual underpinnings related to model specification is preferable to automated model-building approaches in most contexts.

The analysts' choice of model is another important factor, both in terms of conceptualization of the outcome variable and selection of the statistical model. Outcomes can be treated as continuous or binary; treating weight status 
and adiposity as continuous is usually preferable. This can help eliminate outcome misclassification, and this approach considers the entire range of adiposity. ${ }^{69}$ In the studies reviewed here, the construction of regression models varied. Some researchers used stepwise regression techniques to generate the final model. As mentioned above, automated modeling approaches may generate models that are difficult to interpret. Also, such techniques may yield models without important interaction terms which would be appropriate to describe the relationship. Longitudinal studies are the best design to investigate the effect of physical activity and sedentary behavior on the development of obesity, even though these designs are resource intensive in terms of both time and money. ${ }^{72}$ Not all issues are addressed by longitudinal studies, however. For example, even in prospective studies, changing levels of physical activity over time cannot be captured by a single baseline assessment of activity. ${ }^{67,68}$ Thus, the proper analysis of longitudinal data is of consequence; unfortunately, longitudinal data are not always analyzed as such. For example, DuRant directly observed television time in children up to four times over a 1-y period and concluded that there was no relationship between sedentary behavior and increased obesity in 3-4y old children followed for $3 \mathrm{y}^{40}$ It is possible that the choice of outcome, the average of body composition at years 3 and 4 , limited the ability to identify longitudinal change. The increasing availability of software which permits more advanced growth modeling allows for better analysis of longitudinal data. These flexible techniques account for both within-subject and between-subject variation by fitting intercepts and trajectories for each subject and then summarizing the relationship across the sample. Other benefits of application of these models include the ability to account for the correlation between repeated measures on the same subject and the inclusion of subjects with as few as one measurement. The later attribute is efficient and, more importantly, helps to address concern regarding the impact of subject attrition on external validity.

\section{Conclusions}

We reviewed prospective studies on the role of activity and sedentary behavior in the development of elevated weight and adiposity. Research consistently shows the expected, inverse relationship between physical activity and obesity in all but the youngest children. For sedentary behavior, a direct relationship with the development of obesity is seen consistently only before adolescence. These observations may reflect differences in the impacts of these behaviors with age, or may reflect measurement or statistical limitations.

As the research community continues to accrue knowledge in support of preventive interventions, we are challenged to provide a solid evidence base. New measurement approaches are essential to properly capture the effects of new techno- logies, the blending of media, and multi-tasking behaviors. The lack of consistent findings regarding sedentary behavior and weight status in older children may reflect the changing characteristics of the many screens in youth's lives. The second generation of longitudinal studies is beginning to be published, with better use of truly longitudinal statistical approaches.

Public health professionals use the best available information to develop and refine preventive messages and interventions to address the global epidemic of obesity in youth; the research community must meet these needs through improved study designs, measurement methods, and statistical analysis.

\section{References}

1 Mayer J. Genetic, traumatic and environmental factors in the etiology of obesity. Physiol Rev 1953; 33: 472-508.

2 Johnson ML, Burke BS, Mayer J. Relative importance of inactivity and overeating in the energy balance of obese high school girls. Am J Clin Nutr 1956; 4: 37-44.

3 Dietz WH, Gortmaker SL. Preventing obesity in children and adolescents. Annu Rev Public Health 2001; 22: 337-353.

4 Epstein LH, Valoski AM, Vera LS, McCurley J, Wisniewski L, Kalarchian MA, Klein KR, Shrager LR. Effects of decreasing sedentary behavior and increasing activity on weight change in obese children. Health Psychol 1995; 14: 109-115.

5 Epstein LH, Paluch RA, Gordy CC, Dorn J. Decreasing sedentary behaviors in treating pediatric obesity. Arch Pediatr Adolesc Med 2000; 154: 220-226.

6 Faith MS, Berman N, Heo M, Pietrobelli A, Gallagher D, Epstein LH, Eiden MT, Allison DB. Effects of contingent television on physical activity and television viewing in obese children. Pediatrics 2001; 107: 1043-1048.

7 Campbell K, Waters E, O'Meara S, Kelly S, Summerbell C. Interventions for preventing obesity in children. Cochrane Database System Rev 2002; CD001871.

8 Clemmens D, Hayman LL. Increasing activity to reduce obesity in adolescent girls: a research review. J Obstet Gynecol 2004; 33: 801-808.

9 Gortmaker SL, Peterson K, Wiecha J, Sobol AM, Dixit S, Fox MK, Laird N. Reducing obesity via a school-based interdisciplinary intervention among youth: Planet Health. Arch Pediatr Adolesc Med 1999; 153: 409-418.

10 Robinson TN. Reducing children's television viewing to prevent obesity: a randomized controlled trial. JAMA 1999; 282: 1561-1567.

11 Sallis JF, Patrick K. Physical activity guidelines for adolescents. Pediatr Exerc Sci 1994; 6: 302-314.

12 Rowlands AV, Ingledew DK, Eston RG. The effect of type of physical activity measure on the relationship between body fatness and habitual physical activity in children: a metaanalysis. Ann Hum Biol 2000; 27: 479-497.

13 Pratt M, Macera CA, Curtis B. Levels of physical activity and inactivity in children and adults in the United States: current evidence and research issues. Med Sci Sports Exerc 1999; 31: S526-S533.

14 US Department of Health and Human Services. Physical activity and health: a report of the Surgeon General. US Department of Health and Human Services, Public Health Service: Atlanta, GA; 1999.

15 Heath G, Pratt M, Warren C, Kann L. Physical activity patterns in American high school students. results from the 1990 Youth Risk Behavior Survey. Arch Pediatr Adolesc Med 1994; 148: 1131-1136. 
16 Kimm SYS, Glynn NW, Kriska AM, Barton BA, Kronsberg SS, Daniels SR, Crawford PB, Sabry ZI, Liu K. Decline in physical activity in black girls and white girls during adolescence. $N$ Engl $J$ Med 2002; 347: 709-715.

17 Spadano J, Bandini L, Must A, Dallal G, Dietz WH. Longitudinal changes in energy expenditure in girls from late childhood through midadolescence. Am J Clin Nutr 2005; 81: 11021109.

18 Trost SG, Pate RR, Sallis JF, Freedson PS, Taylor WC, Dowda M, Sirard J. Age and gender differences in objectively measured physical activity in youth. Med Sci Sports Exerc 2002; 34: 350-355.

19 Caspersen CJ, Pereira MA, Curran KM. Changes in physical activity patterns in the United States, by sex and cross-sectional age. Med Sci Sports Exerc 2000; 32: 1601-1609.

20 Sallis JF. Epidemiology of physical activity and fitness in children and adolescents. Crit Rev Food Sci Nutr 1993; 33: 403-408.

21 Malina R. Fitness and performance: adult health and the culture of youth, new paradigms?. In: Park RJ, Eckert MH (eds). New possibilities, new paradigms?. Human Kinetics Publishers: Champaign, IL; 1991. pp 30-38.

22 Welk GJ, Corbin CB, Dale D. Measurement issues in the assessment of physical activity in children. Res Quart Exerc Sports 2000; 71: S59-S73.

23 Sirard JR, Pate RR. Physical activity assessment in children and adolescents. Sports Med 2001; 31: 439-454.

24 Trost SG. Objective measurement of physical activity in youth: current issues, future directions. Exercise Sport Sci Rev 2001; 29: $32-36$

25 Trost SG, Pate RR, Freedson PS, Sallis JF, Taylor WC. Using objective physical activity measures with youth: How many days of monitoring are needed? Med Sci Sports Exerc 2000; 32: 426-431.

26 Sallis JF, Zabinski MF. Measurement of physical activity. In: Fairburn CG, Brownell KD (eds). Eating disorders and obesity 2nd edn. Guilford: New York; 2002.

27 Anderson SE, Bandini LG, Dietz WH, Must A. Relationship between temperament, nonresting energy expenditure, body composition, and physical activity in girls. Int J Obes Relat Metab Disord 2004; 28: 300-306.

28 Anderson SE, Bandini LG, Must A. Child temperament does not predict adolescent body composition in girls. Int $J$ Obes Relat Metab Disord 2005; 29: 47-53.

29 Dietz WH. The role of lifestyle in health: the epidemiology and consequences of inactivity. Proc Nutr Soc 1996; 55: 829-840.

30 Dietz WH, Bandini LG, Morelli JA, Peers KF, Ching PLYH. Effect of sedentary activities on resting metabolic rate. Am J Clin Nutr 1994; 59: 556-559.

31 Segal KR, Dietz WH. Physiologic responses to playing a video game. Am J Dis Child 1991; 145: 1034-1036.

32 Ainsworth BE, Haskell WL, Leon AS, Jacobs DRJ, Montoye HJ, Sallis JF, Paffenbarger RSJ. Compendium of physical activities: classification of energy costs of human physical activities. Med Sci Sports Exerc 1993; 25: 71-80.

33 Montgomery KC. Children's media culture in the new millennium: mapping the digital landscape. Future Child 2000; 10: 145-167.

34 Wang Y, Monteiro C, Popkin BM. Trends of obesity and underweight in older children and adolescents in the United States, Brazil, China, and Russia. Am J Clin Nutr 2002; 75: 971-977.

35 Moore LL, Nguyen U-S, Rotman KJ, Cupples LA, Ellison RC. Preschool physical activity level and change in body fatness in young children. The Framingham Children's Study. Am J Epidemiol 1995; 142: 982-988.

36 Anderson DR, Field DE, Collins PA, Lorch EP, Nathan JG. Estimates of young children's time with television: a methodo- logical comparison of parent reports with time-lapse video home observation. Child Dev 1985; 56: 1345-1357.

37 Borzekowski DLG, Robinson TN. Viewing the viewers: ten video cases of children's television viewing behaviors. I Broadcast Electron Media 1999; 43: 506-528.

38 Stettler N, Signer TM, Suter PM. Electronic games and environmental factors associated with childhood obesity in Switzerland. Obes Res 2004; 12: 896-903.

39 Roberts DF, Foehr U, Rideout V. Generation M: media in the lives of 8-18 year olds. Report \# 7251. Kasier Family Foundation: Menlo Park, CA; 2005. [ www.kff.org ].

40 Durant RH, Baranowski T, Johnson M, Thompson WO. The relationship among television watching, physical activity, and body composition of young children. Pediatrics 1994; 94: 449-456.

41 Dennison BA, Erb TA, Jenkins PL. Television viewing and television in bedroom associated with overweight risk among low-income preschool children. Pediatrics 2002; 109: 10281035.

42 Pietrobelli A, Faith MS, Allison DB, Gallagher D, Chiumello G, Heymsfield SB. Body mass index as a measure of adiposity among children and adolescents: a validation study. $J$ Pediatr 1998; 132: 204-210.

43 Freedman DS, Dietz WH, Srinivasan SR, Berenson GS. The relation of overweight to cardiovascular risk factors among children and adolescents: the Bogalusa Heart Study. Pediatrics 1999; 103: 1175-1182.

44 Must A. Morbidity and mortality associated with elevated body weight in children and adolescents. Am J Clin Nutr 1996; 63 445S-447S.

45 Must A, Strauss RS. Risks and consequences of childhood and adolescent obesity. Int J Obes Relat Metab Disord 1999; 23: S2-S11.

46 Ogden CL, Flegal KM, Carroll MD, Johnson CL. Prevalence and trends in overweight among US children and adolescents, 19992000. JAMA 2002; 288: 1728-1732.

47 Cole TJ, Bellizzi MC, Flegal KM, Dietz WH. Establishing a standard definition for child overweight and obesity worldwide: international survey. BMJ 2000; 320: 1240-1243.

48 Moore LL, Gao D, Bradlee ML, Cupples LA, SundarajanRamamurti A, Proctor MH, Hood MY, Singer MR, Ellison RC. Does early physical activity predict body fat change throughout childhood? Prevent Med 2003; 37: 10-17.

49 Bullen BA, Mayer J, Reed RB. Physical activity of obese and nonobese adolescent girls appraised by motion picture sampling. Am J Clin Nutr 1964; 14: 211-217.

50 Corbin CB, Pletcher P. Diet and physical activity patterns of obese and nonobese elementary school children. Res $Q$ 1968; 39: 922-928.

51 Eck LH, Klesges RC, Hanson CL, Slawson D. Children at familial risk for obesity: an examination of dietary intake, physical activity and weight status. Int J Obes Relat Metab Disord 1992; 16 71-78.

52 Trost SG, Sirard JR, Dowda M, Pfeiffer KA, Pate RR. Physical activity in overweight and nonoverweight preschool children Int J Obes Relat Metab Disord 2003; 27: 834-839.

53 Janz KF, Levy SM, Burns TL, Torner JC, Willing MC, Warren JJ. Fatness, physical activity, and television viewing in children during the adiposity rebound period: The Iowa Bone Development Study. Prev Med 2002; 35: 563-571.

54 Abbott RA, Davies PSW. Habitual physical activity and physical activity intensity: their relation to body composition in 5.010.5-y-old children. Eur J Clin Nutr 2004; 58: 285-291.

55 Patrick K, Norman GJ, Calfas KJ, Sallis JF, Zabinski MF, Rupp J, Cella J. Diet, physical activity, and sedentary behaviors as risk factors for overweight in adolescence. Arch Pediatr Adolesc Med 2004; 158: 385-390.

56 Klesges RC, Haddock K, Eck LH. A multimethod approach to the measurement of childhood physical activity and its relationship to blood pressure and body weight. J Pediatr 1990; 116: 888-893. 
57 McMurray RG, Harrell JS, Deng SB, Bradley CB, Cox LM, Bangdiwala SI. The influence of physical activity, socioeconomic status, and ethnicity on the weight status of adolescents. Obes Res 2000; 8: 130-139.

58 Gazzaniga JM, Burns TL. Relationship between diet composition and body fatness, with adjustment for resting energy expenditure and physical activity, in preadolescent children. Am J Clin Nutr 1993; 58: 21-28.

59 Klein-Platat C, Oujaa M, Wagner A, Haan MC, Arveiler D, Schlienger JL, Simon C. Physical activity is inversely related to waist circumference in 12-y-old French adolescents. Int J Obes Relat Metab Disord 2005; 29: 9-14.

60 Ekelund U, Neovius M, Linne Y, Brage S, Wareham NJ, Rossner S. Associations between physical activity and fat mass in adolescents: The Stockholm Weight Development Study. Am J Clin Nutr 2005; 81: 355-360.

61 Elgar FJ, Roberts C, Moore L, Tudor-Smith C. Sedentary behaviour, physical activity and weight problems in adolescents in Wales. Public Health 2005; 119: 518-524.

62 Reynolds KD, Killen JD, Bryson SW, Maron DJ, Taylor CB, Maccoby N, Farquhar JW. Psychosocial predictors of physical activity in adolescents. Prev Med 1990; 19: 541-551.

63 Janssen I, Craig WM, Boyce WF, Pickett W. Associations between overweight and obesity with bullying behaviors in school-aged children. Pediatrics 2004; 113: 1187-1194.

64 Faith MS, Leone MA, Ayers TS, Heo M, Pietrobelli A. Weight criticism during physical activity, coping skills, and reported physical activity in children. Pediatrics 2002; 110: e23.

65 Stevens J, Suchindran C, Ring K, Baggett CD, Jobe JB, Story M, Thompson J, Going SB, Caballero B. Physical activity as a predictor of body composition in American Indian children. Obes Res 2004; 12: 1974-1980.

66 Jago R, Baranowski T, Baranowski JC, Thompson D, Greaves KA. BMI from 3-6y of age is predicted by TV viewing and physical activity, not diet. Int J Obes Relat Metab Disord 2005; 29: 557-564.

67 Kettaneh A, Oppert JM, Heude B, Deschamps V, Borys JM, Lommez A, Ducimetiere P, Charles MA. Changes in physical activity explain paradoxical relationship between baseline physical activity and adiposity changes in adolescent girls: the FLVS II study. Int J Obes Relat Metab Disord 2005; 29: 586-593.

68 O'Loughlin J, Gray-Donald K, Paradis G, Meshefedjian G. Oneand two-year predictors of excess weight gain among elementary schoolchildren in multiethnic, low-income, inner-city neighborhoods. Am J Epidemiol 2000; 152: 739-746.

69 Berkey CS, Rockett HRH, Field AE, Gillman MW, Frazier AL, Camargo CA, Colditz GA. Activity, dietary intake, and weight changes in a longitudinal study of preadolescent and adolescent boys and girls. Pediatrics 2000; 105: E56.

70 Gordon-Larsen P, Adair LS, Popkin BM. Ethnic differences in physical activity and inactivity patterns and overweight status. Obes Res 2002; 10: 141-149.

71 Stice E, Presnell K, Shaw H, Rohde P. Psychological and behavioral risk factors for obesity onset in adolescent girls: a prospective study. J Consult Clin Psychol 2005; 73: 195-202.

72 Klesges RC, Klesges LM, Eck LH, Shelton M. A longitudinal analysis of accelerated weight gain in preschool children. Pediatrics 1995; 95: 126-130.

73 Maffeis C, Talamini G, Tato L. Influence of diet, physical activity and parents' obesity on children's adiposity: a four-year longitudinal study. Int J Obes Relat Metab Disord 1998; 22: 758-764.

74 Davison KK, Birch LL. Child and parent characteristics as predictors of change in girls' body mass index. Int J Obes Relat Metab Disord 2001; 25: 1834-1842.

75 Salbe AD, Weyer C, Harper I, Lindsay RS, Ravussin E, Tataranni PA. Assessing risk factors for obesity between childhood and adolescence: II. Energy metabolism and physical activity. Am J Clin Nutr 2002; 110: 307-314.

76 Bogaert N, Steinbeck KS, Baur LA, Brock K, Bermingham MA. Food, activity and family-environmental vs biochemical predictors of weight gain in children. Eur I Clin Nutr 2003; 57: $1242-1249$

77 Burke V, Beilin LJ, Simmer K, Oddy WH, Blake KV, Doherty D, Kendall GE, Newnham JP, Landau LI, Stanley FJ. Predictors of body mass index and associations with cardiovascular risk factors in Australian children: a prospective cohort study. Int $J$ Obes Relat Metab Disord 2005; 29: 15-23.

78 Horn OK, Paradis G, Potvin L, Macaulay AC, Desrosiers S. Correlates and predictors of adiposity among Mohawk children. Prev Med 2001; 33: 274-281.

79 Kemper HCG, Post GB, Twisk JWR, van Mechelen W. Lifestyle and obesity in adolescence and young adulthood: results from the Amsterdam Growth And Health Longitudinal Study (AGAHLS). Int J Obes Relat Metab Disord 1999; 23: S34-S40.

80 Hernandez B, Gortmaker SL, Colditz G, Peterson KE, Laird NM, Parra-Cabrera S. Association of obesity with physical activity, television programs and other forms of video viewing among children in Mexico City. Int J Obes Relat Metab Disord 1999; 23: 845-854.

81 Gortmaker SL, Must A, Sobol AM, Peterson K, Colditz GA, Dietz WH. Television viewing as a cause of increasing obesity among children in the United States, 1986-1990. Arch Pediatr Adolesc Med 1996; 150: 356-362.

82 Obarzanek E, Schreiber GB, Crawford PB, Goldman SR, Barrier PM, Frederick MM, Lakatos E. Energy-intake and physicalactivity in relation to indexes of body-fat - the National Heart, Lung, and Blood Institute Growth and Health Study. Am J Clin Nutr 1994; 60: 15-22.

83 Andersen RE, Crespo CJ, Bartlett SJ, Cheskin LJ, Pratt M. Relationship of physical activity and television watching with body weight and level of fatness among children: results from the Third National Health and Nutrition Examination Survey. IAMA 1998; 279: 938-942.

84 Deheeger M, Rolland-Cachera MF, Fontvieille AM. Physical activity and body composition in 10 year old French children: linkages with nutritional intake? Int J Obes Relat Metab Disord 1997; 21: 372-379.

85 Guillaume M, Lapidus L, Bjorntorp P, Lambert A. Physical activity, obesity, and cardiovascular risk factors in children. The Belgian Luxembourg Child Study II. Obes Res 1997; 5: 549-556.

86 Ma GS, Li YP, Hu XQ, Ma WJ, Wu J. Effect of television viewing on pediatric obesity. Biomed Environ Sci 2002; 15: 291-297.

87 von Kries R, Toschke AM, Koletzko B, Slikker W. Maternal smoking during pregnancy and childhood obesity. Am J Epidemiol 2002; 156: 954-961.

88 Tremblay MS, Willms JD. Is the Canadian childhood obesity epidemic related to physical inactivity? Int J Obes Relat Metab Disord 2003; 27: 1100-1105.

89 Wake M, Hesketh K, Waters E. Television, computer use and body mass index in Australian primary school children. I Paediatr Child Health 2003; 39: 130-134.

90 Robinson TN, Hammer LD, Killen JD, Kraemer HC, Wilson DM, Hayward C, Taylor CB. Does television viewing increase obesity and reduce physical activity? Cross-sectional and longitudinal analyses among adolescent girls. Pediatrics 1993; 91: 273-280.

91 Wolf AM, Gortmaker SL, Cheung L, Gray HM, Herzog DB, Colditz GA. Activity, inactivity, and obesity: racial, ethnic, and age differences among schoolgirls. Am J Public Health 1993; 83: $1625-1627$

92 da Costa Ribeiro I, Augusto AC, Taddei J, colugnatti F. Obesity among children attending elementary public schools in Sao Paulo, Brazil:a case control study. Public Health Nutr 2003; 6: 4.

93 Locard E, Mamelle N, Billette A, Miginiac M. Risk factors of obesity in a five year old population. Parental versus environmental factors. Int J Obes Relat Metab Disord 1992; 16: 721-729.

94 Marshall SJ, Biddle SJH, Gorely T, Cameron N, Murdey I. Relationships between media use, body fatness and physical activity in children and youth: a meta-analysis. Int J Obes Relat Metab Disord 2004; 28: 8. 
95 Strauss RS, Pollack HA. Social marginalization of overweight children. Arch Pediatr Adolesc Med 2003; 157: 746-752.

96 Francis LA, Lee Y, Birch LL. Parental weight status and girls' television viewing, snacking, and body mass indexes. Obes Res 2003; 11: 143-151.

97 Proctor $\mathrm{MH}$, Moore LL, Gao D, Cupples LA, Bradlee ML, Hood MY, Ellison RC. Television viewing and change in body fat from preschool to early adolescence: The Framingham Children's Study. Int J Obes Relat Metab Disord 2003; 27: 827-833.
98 Davison KK, Birch LL. Childhood overweight: a contextual model and recommendations for future research. Obes Rev 2001; 2: 159-171.

99 Kimm SYS, Obarzanek E, Barton BA, Aston CE, Similo SL, Morrison JA, Sabry ZI, Schreiber GB, McMahon RP. Race, socioeconomic status, and obesity in 9- to 10 year-old girls: the NHLBI growth and health study. Ann Epidemiol 1996; 6: 266-275.

100 Flegal KM, Kusczmarski RJ, Johnson CL. Overweight and obesity in the United States: prevalence and trends, 1960-1994. Int J Obes Relat Metab Disord 1998; 22: 39-47. 